\title{
Towards a Kantian theory of philosophical education and wisdom-with the help of Hannah Arendt
}

\author{
(Preprint. Forthcoming in the Journal of Philosophy of Education)
}

\author{
Helga Varden
}

\section{INTRODUCTION}

In the Metaphysics of Morals, Kant argues that the 'beginning of human wisdom' is to 'know your heart' - an endeavour that is truly difficult, yet constitutive of pursuing the highest good or realising ourselves fully (Kant, 1996a, p. 562 [6: 441]). The highest good, in turn, 'consists in the union and harmony of... human morality... and human happiness' (Kant, 1996a, p. 282 [8: 279]). Kant furthermore argues that even though the highest good is 'the whole, the complete good,' because morality is 'the supreme [unconditional] good' while 'happiness is something that, though always pleasant to the possessor of it, is not of itself absolutely and in all respects good' (i.e. it is conditionally good), morality sets the framework within which happiness must be pursued (Kant, 1996a, p. 229 [5: 110-111])). In many regards, Kant himself certainly failed in his efforts at becoming wise. Kant yielded to temptations to seriously dehumanise others and himself-for example, he was, undeniably, racist, sexist and heterosexist. Indeed, Kant's life shows us that it is possible to be a philosopher who revolutionises our thinking about morality in terms of freedomin fact, to be the first to propose that treating others morally is to treat them with respect or as having dignity — while simultaneously dehumanising himself and others. It presumably follows from this that we can teach our students Kant's brilliant theories of morality as freedom without thereby giving them access to all the philosophical resources they need to become wise, good people. In fact, as we shall see below, having access to philosophical education can make us unhappy, arrogant, or alienated from ourselves, others and society. This paper also suggests that to remedy this problem in Kant's philosophy, it helps to bring it into conversation with Hannah Arendt on the topics of human nature, philosophical education and wisdom within the context of modern life. ${ }^{\text {ii }}$ Together, I propose, their theories make it easier to appreciate the emotional importance of what Kant calls our animality and our natural vital force, as well as how philosophical reflection and theorising are, paradoxically, both constitutive of becoming wiser human beings and sources of emotional challenges that make it more difficult to achieve wisdom. Indeed, I suggest, Kant's own failures at achieving wisdom are not accidentally related to these challenges—as are those of much ideal theory today.

To make my case, my first section ('Arendt on the Human Condition and Modernity') sketches Arendt's accounts of the human condition and our modern selves. I pay special attention to her criticism of the Western philosophical canon's tendency to rank human lives in a hierarchy where the philosopher's contemplative life reigns supreme, and her related proposal that our modern selves are dangerously ungrounded. The following section ('Kant on Human Nature'), in contrast, outlines Kant's account of how practical reasoning puts us at a reflective distance from our natural, conscious strivings, in a way that entails that philosophical reasoning is only indirectly conducive to happiness. This, in turn, is why those trained in philosophy can start to hate reason and become envious of those less educated because they seem happier. I then sketch Kant's accounts of the highest good and human nature. This enables us to see that Kant's own deep philosophical commitments should have been matched by much listening and caution when engaging, let alone judging, various types of human lives and historical societies. Indeed, both his theories and his personal failures help us appreciate why the switch from ideal to non-ideal theorising must be 
matched with a methodological switch from a top-down to a bottom-up approach. Doing so is necessary to stay truthful to the lives we are philosophically critiquing rather than unwittingly using philosophical theory to engage in dehumanising practices regarding various social groups and lives. This may be one reason why many deep, revolutionary philosophical thinkers who were subjected to dehumanising oppression and violence, including Arendt, seem to intuitively have known the importance of such a bottom-up approach when thinking about these complexities of their lives. I also propose that incorporating this approach when we teach is constitutive of providing our students with conditions in which they can strive to become, not only philosophically knowledgeable and smart, but wiser human beings. I conclude by emphasising that none of this is to say that ideal philosophical theorising, such as about the principles of freedom, is unimportant in education, in our lives or while theorising. Quite the contrary; wise human lives and theories require both activities: top-down ideal theory and bottom-up non-ideal theory. It is important, I argue, not to lose sight of the fact that modern theories of freedom — with Kant's being an extremely powerful onewere truly revolutionary in promoting moral progress, just as accessible, higher philosophical education is a gamechanger in individual lives and societies. More generally, I defend Kant's basic proposal that more complete practical philosophical theories must let the ideal principles of freedom set the framework within which we make space for our distinctly human or historical conditions.

\section{ARENDT ON THE HUMAN CONDITION AND MODERNITY}

One intriguing proposal in Hannah Arendt's The Human Condition is that the Western philosophical tradition has contributed to the existence of certain problems characteristic of modern lives because it has tended to rank different kinds of lives in a hierarchy with the reflective, philosophical way of life identified as the best. To see this, I first sketch Arendt's general account of our embodied, social, rational human nature before using it to show why she thinks that problems that in Ancient Greece were characteristic of philosophical theories, as well as the lives of philosophers, have now transformed in our modern world into more general problems for everyone.

According to Arendt's account of the human condition, we can divide our conscious activity into four distinct types, the first three of which — labour, work, and action ${ }^{\mathrm{iii}}$ — constitute 'vita activa' (Arendt, 1998, pp. 7-8), while the last — philosophical contemplation—makes up 'vita contemplativa' (pp. 14-17). Labour, in turn, is defined as 'the activity which corresponds to the biological process of the human body' (p. 7). It refers to all reproductive activity that sustains us as biological organisms - such as cooking, cleaning, producing firewood, caring for children and the sick, etc.and in Ancient Greek society, this was the private activity in the home that was ideally undertaken by slaves (p. 7). Second, there is work, which 'is the activity which corresponds to the unnaturalness of human existence' and 'provides an "artificial” world of things' (p. 7). Work, then, is activity that creates an artificial human world by means of creating useable objects—such as buildings, tools, roads, bridges, etc. - that last through time. Work, therefore, is characteristically the activity of craftspeople (p. 7). Third, there is 'action,' which is 'the only activity that goes on directly between men and without the intermediary of things or matter, [and it] corresponds to the human condition of plurality, to the fact that men, not Man, live on Earth and inhabit the world. While all aspects of the human condition are somehow related to politics, this plurality is specifically the condition... of all political life' (p. 7). Action is political activity in which citizens use words and speech spontaneously and together as free and equal—publicly — to come up with the laws and policies by means of which a shared, evolving political sphere is created and maintained. Action also reflects the fact that as a species, we are plural in that there is no one way to live life; indeed, 'nobody is the same as anyone else who ever lived, lives, or will live' (p. 8). Hence, creating a shared political society together is an ongoing activity that is up for renewal and change with each new member because 
'each newcomer possesses the capacity of beginning something anew, that is, of acting' (which Arendt also calls 'natality') (p. 9). The aim of action, so understood, is to partake in the creation of an immortal society, one that lasts through time and is captured by a rich history as enabled by artists, writers, and scholars. Finally, there is philosophical contemplation, which goes beyond the human condition altogether, including action, in how it aims at truth: 'Every movement, the movement of body and soul as well as of speech and reasoning, must cease before truth. Truth, be it the ancient truth of Being or the Christian truth of the living God, can reveal itself only in complete human stillness' (p. 15). Philosophical contemplation is, in other words, pure rational activity directed towards uncovering eternal universal truths - truths of the universe-which are only available insofar as we do not engage in human labour, work or action, but are completely still.

To illustrate these ideas, consider Arendt's example of the USSR's launching of the satellite Sputnik into orbit around our planet in 1957. If we use the above concepts to describe this event, we can say that it could not have happened unless there had been: much labour spent on keeping all the people involved in it sufficiently safe and healthy (fed, rested, clothed, etc.); much work spent on producing all the physical objects - the shell, the engine, the instruments, etc.-constituting the satellite as well as all the other world-constituting objects needed for this project to succeed; much action in USSR politics that involved envisioning and politically organising the institutional efforts making this launch possible; and, finally, much philosophical contemplation in the sense of various philosophical discoveries throughout the centuries as well as much scientific thought that was fundamentally enabled by this philosophical contemplation. All this activity made it possible to find a way to make a human-made object leave planet Earth and move in an orbit around the planet. This achievement was, in Arendt's view, 'second in importance to no other,' not only because it required such incredible human accomplishments, but because it involved directly engaging the universe beyond our planet by scientific means for the first time (p. 1). Setting aside the political drama of the event-it happened in the middle of the Cold War-Arendt proposes that the event was philosophically so important also because of the way in which so many people, across nations, spontaneously responded to it. The predominant response was similar to the one expressed on the graveside obelisk of one of the great Russian scientists, namely that 'Mankind will not remain bound to the earth forever' (p. 1). The philosophical puzzle, Arendt argues_-and then posits as a main topic to be explored in The Human Condition - is that instead of finding it amazing that we now can engage in the universe in this way, many expressed existential relief that perhaps we can leave this planet soon. How can we explain that human beings who reside on an incredible, utterly stunning planet experience earthly life as analogous to being imprisoned and hence spontaneously express such a deep longing to leave it behind?

Arendt's answer to this question of modern human alienation from our earthly selves is complex. To start, she suggests that even though the various accounts of human nature on offer in the Western philosophical tradition differ in how they construe our more animalistic, social and rational parts, they are commonly arranged in a hierarchy where the rational parts - the ones realised most fully by philosophers - reign at the top. Moreover, she proposes that one source of the convictions that philosophers have the best lives and have the best judgment of all moral matters, including of the functioning of our public institutions (indeed, for Plato, that philosophers should be in charge of society as 'philosopher kings'), is the belief that they experience the highest or best- the most divine-type of pleasure there is for humans. Philosophers obtain this type of pleasure by engaging in philosophical contemplation, which involves experiencing a 'kind of death' (p. 20). This small death refers to how, while being submerged in philosophical contemplation, we subjectively experience the absence of our earthly human selves. That is to say, the activity of philosophical contemplation is one in which we no longer have a subjective sense of our own body or of our own self (the reflectively self-conscious 'I') even though contemplating philosophical truths_or leaving 
the cave behind, to say it with Socrates and Plato-is an activity we can do on our own or together with others, the moments of grasping truths ('getting it') is something we can only do 'singularly' (on our own) (p. 20). Hence, when we employ our rational powers in philosophical contemplation, we experience a small death that, paradoxically and incredibly, can get us to eternal truths of the universe.

To illustrate this point of Arendt's further, remember how Aristotle in his Book 10 of the Nicomachean Ethics proposes that pure philosophical contemplation is the most divine experience possible for humans because it enables the highest-the most 'pleasant,' 'pure,' 'stable,' 'selfsustainable,' and 'self-sufficient' - form of pleasure there is for us (see Aristotle, 2000, pp. 194-199 [1177a-1179a]). To clarify Aristotle's argument, we can draw on the French expression that orgasm is 'le petit mort.' An orgasm, in other words, also involves a momentary loss of both our sense of our own embodiment and the reflective sense of ' $\mathrm{I}$ ' (reflective self-consciousness), and it is something we can only experience singularly. Moreover, although only I can experience my own orgasm, I can pursue it on my own or together with others. ${ }^{\text {iv }}$ Aristotle's proposal is that philosophical contemplation is of a higher quality - 'une mort un peu plus grande' - than an orgasm even though they are both, we can say with Arendt, experiences of small deaths. ${ }^{v}$ In addition, remember that when we engage in philosophical contemplation, we can subjectively experience truths of the universe and not our own or earthly living (p. 20). It is not so strange therefore that once philosophy starts in a society, those engaged in it can easily become spellbound by its pleasures. Because philosophical contemplation opens up human life and reality in new ways, is not restricted to life on the planet, and involves a distinctive kind of deep pleasure, it becomes easy for philosophers (and others) to conclude that the different parts of our lives can be organised in a hierarchy, with the more biological or animalistic parts - the ones we share with other earthly biological beings (plants and animals) - being located at the bottom, while the social and cultural ones are found at the next, higher level, before, finally, the rational and philosophical parts reign at the top.

Arendt does not doubt 'the validity of the experience' underlying the distinction between vita activa (labour, work, and action) and vita contemplativa (philosophical contemplation) (p. 18). Rather, she challenges 'the hierarchical order inherent in it from its inception' in Ancient Greek philosophy (p. 17). She argues that it is a mistake to organise these different aspects of our lives into a hierarchy with the explicit or implicit aim of ridding ourselves of the 'lower' parts, and maybe vita activa altogether, by making it a 'handmaiden' for philosophical contemplation (p. 21). Arendt furthermore thinks that these hierarchical tendencies in Ancient Greek (and most subsequent) philosophy, according to which vita activa and vita contemplativa are viewed as distinctive activities where the latter should rule the former, were helped along by the fall of the Roman Empire (which crushed the notion that humans can create immortal societies) and Christianity (with its notion of an everlasting individual): 'Both together made any striving for an earthly immortality futile and unnecessary' (p. 21).

Turning to modernity, Arendt proposes that the scientific revolution together with various important modern liberatory movements undertaken in the name of equality, such as the labour and women's rights movements, freed much of human life from being bound to or enslaved by reproductive needs. Arendt's view is not that we should glorify or romanticise labour. After all, doing only labour is emotionally draining for us because it is so centrally focused on sheer reproductive activities - a concern that feminist philosophy characteristically has given voice to (since women typically have had to do much of the labour in lower social classes or in societies where slavery was illegal). Nevertheless, Arendt emphasises that a tempting, yet mistaken inference one can draw is that labour does not have any value at all. Labour, Arendt proposes instead, is an emotionally grounding activity constitutive of our private sphere-of the 'hearth' in the home. It is emotionally grounding because it makes us engage in activity tuned into the cyclical biological 
processes constitutive of all, including human, organic life on the planet. In pre-modern times, our vulnerabilities in relation to sickness, weather, the seasons, etc., entailed that human life itself regularly drew everyone back to this cyclical activity, while in modernity, this no longer happens because of the ways in which modern science (including medicine) and societal organisation make it possible for many (and not just the elite) to spend much less time on labour. Yet, consequentially, we have become importantly ungrounded emotionally; we no longer emotionally integrate our animalistic, earthly being in good, sustaining ways.

Importantly, Arendt does not think that the problem we are inheriting is simply that philosophers have tended to put human lives into a hierarchy and then declared philosophical contemplation the best life. In addition, she argues that 'the enormous weight of contemplation in the traditional hierarchy has blurred the distinctions and articulations within the vita activa itself... [a] condition [that] has not changed essentially by the modern break with the tradition and the eventual reversal of its hierarchical order in Marx and Nietzsche... the conceptual framework is left more or less intact' (p. 17). Starting with the last point, Arendt argues that even if we re-arrange the traditional hierarchy and, with, say, Marx, put (his conception of) labour at the top, the fundamental mistake is still there in that the various kinds of valuing activity are organised in a hierarchy. Moreover, and this brings us to the first point, Marx also has a fuzzy view of the distinctions within vita activa (between labour, work, and action), which is why his overall analysis yields an insufficiently complex account of these aspects of our being. Let us slow down a little to clarify both points.

Our loss of a sense of the importance of labour is, Arendt proposes, accompanied by a meshing into one of all the distinctive valuing activities-labour, work, action, and contemplation. Whether we think of labour theories such as those of Karl Marx, Adam Smith, or John Locke or just modern common sense, all value-creating activity is typically thought of as only one kind, for which we use the words 'labour' or 'work' interchangeably. Hence, whether we are bus drivers or mechanics, shopkeepers or farmers, monarchs or prime ministers, schoolteachers or professional philosophers, we are all just doing a job for which we get paid, and our doing it well is measured by how much money we make or how much - how many objects-we 'produce.' Although many languages and old phrases, such as Locke's famous phrase 'the labour of my body, and the work of my hands' tracks the distinction between labour and work, there is no theoretical or common awareness of different types of activities and objects involved in the two kinds of activities (pp. 103f.). This, in turn, is related to how the judgement about whether we are, say, successful as philosophers, is centrally connected to how many students we teach or how many papers we publish (rather than the quality of the teaching or the research). Similarly, whether we do well as a society depends on how many objects we produce or sell—this will improve our annual reports, increase our profits, raise the GDP, etc.-rather than on whether the objects produced are of a kind suited to the activity in which they are used and whether they enable flourishing and sustainable life on the planet. For example, because we have lost the distinction between labour and work, we now use plastic objects as part of our carry-out meals and call them 'disposable' even though a plastic object really is not disposable. A plastic object is an object of work and not labour. This is not to say that plastic is a bad product - it is an amazing product - but it is an object of work and not labour, which is why it cannot be treated as, say, a 'disposable' part of a carry-out meal. Objects of labour are cyclical (as they track biological processes of sustainable reproduction), while objects of work are linear (as they are constitutive of efforts to create an artificial world that lasts through time). Hence, tools like a cup, a plate, cutlery, or a pot (objects of work) should, as a general rule, be used repeatedly as part of the production of many meals (objects of labour). When we need artifacts that will only be used once, such as if we suddenly need to improvise when hiking in the mountains or for the purpose of carry-out meals, then we must make sure these artifacts are truly disposable, such as by using branches of trees as cooking tools when hiking or recyclable containers for carry-out 
meals. Hence, our loss of distinction between labour and work is one reason why we face the enormous environmental problems we do currently on the planet as well as the problem of consumerism characteristic of our societies. Moreover, whether we put 'contemplation' or (Marx's notion of) 'labor' at the top, Arendt suggests, the fundamental problems are that we have lost a sense of different kinds of value and that we mistakenly strive to organize all valuing activity into such hierarchies.

\section{KANT ON HUMAN NATURE}

Kant's philosophy uncontroversially avoids some of the problems Arendt views as characteristic of the Western philosophical tradition. Kant and philosophers following his lead characteristically put our human capacity for autonomy at the centre of their analyses of ethics (virtuous internal freedom) and right (rightful external freedom). Kantian analyses of virtue correspondingly tend to focus on Kant's proposals regarding the moral law, the categorical imperative, perfect and imperfect duties, and acting from duty, while Kantian analyses of right characteristically focus on Kant's account of the 'Doctrine of Right' with its accounts of the Universal Principle of Right, of innate, private, and public right. Both kinds of Kantian analysis_-of virtue and of right_-are deeply consistent with Arendt's central claims that human beings are irreducibly different from one another, that there is no hierarchy of value characteristic of different types of life (the life of the philosopher is not more valuable than the life of the soccer player), and that philosophers do not have the best judgments of our public institutions and certainly should not oversee or govern the rest of humanity as philosopher kings. Before turning to the ways in which Kant or the Kantian philosophical tradition nonetheless have important lessons to learn from Arendt-even though, in my view, the multifaceted systematicity of Kant's philosophical position is better than Arendt's-let me show how Kant adds to Arendt's analysis of the dangers of doing philosophy.

Although it is not widely known, Kant argues that learning to reason philosophically and, indeed, living a philosopher's life, is an activity that comes with the destructive temptations to start hating reason and become envious of those who do not put philosophical reasoning at the core of their lives. This is not to say that Kant thinks we shouldn't do practical philosophy or that there are no good reasons why human beings start doing it; in fact, Kant thinks we start doing practical philosophy because we often find ourselves in trouble in life (when living without it). He argues that even though ' $[\mathrm{t}]$ here is something splendid about innocence... what is bad about it... is that it cannot protect itself very well and is easily seduced' (Kant, 1996a, pp. 58-60 [4: 404-5]). So, we start doing philosophy in part to overcome the troubles characteristic of innocent lives, but, Kant continues, some of the perplexity of learning to reason philosophically does not actually make us happier as such. In fact, because of its inherently reflective and abstract conceptual nature (more on this below), reasoning puts us at a distance from, rather than closer to happiness. Kant argues that

the more a cultivated reason purposely occupies itself with the enjoyment of life and with happiness, so much the further does one get away from true satisfaction; and from there arises in many, and indeed in those who have experimented most with this use of reason, if only they are candid enough to admit it, a certain degree of misology, that is, hatred of reason; for, after calculating all the advantages they draw... they find that they have in fact only brought more trouble upon themselves instead of gaining in happiness; and because of this they finally envy rather than despise the common run of people, who are closer to the guidance of mere natural instinct and do not allow their reason much influence on their behavior. (Kant, 1996a, p. 51 [4: 395-6]) 
In addition to this problem of hating reason and being envious of those who live happier lives without it, there is the problem that being unhappy but good at philosophical reasoning makes us liable to arrogance. If we yield to this temptation-something which, as Arendt points out, seems to have been the case for Socrates, Plato, and Aristotle - then we are likely to despise or look down upon those who are happy even though they are not as philosophically reflective. Both the envious and the arrogant philosopher reveal, in other words, emotional challenges that come with learning to reason philosophically.

There is no quick fix to these challenges of life: we need philosophy to become wiser, but doing philosophy sets us further apart from happiness, while, contrarily, pursuing happiness without philosophy (innocence) makes us liable to lose our way easily and become very seducible. To put this point from a different direction, we may say that although wise persons know and protect what makes them happy, they also recognise and value what philosophy has to offer. Kant relatedly argues that because doing what is right — exercising moral responsibility — often makes reason-based claims on us that go against our 'needs and inclinations' (happiness) and they do so 'unremittingly,' and 'without thereby promising anything to inclinations[, ... there arises a natural dialectic... a propensity to rationalise against those strict laws of duty and to cast doubt upon their validity... or... purity and strictness... to make them better suited to our wishes and inclinations' (Kant, 1996a, pp. 59-60 [4: 405]). Because of this danger, wisdom — 'which... consists more in conduct than in knowledge'needs philosophy's help by 'provid[ing] access and durability for its precepts' (Kant, 1996a, p. 59 [4: 405]). More specifically, the systematicity of philosophy provides

information and distinct instruction regarding the source of its [common human reason's] principle and the correct determination of this principle in comparison with maxims based on need and inclination so that it may escape from its predicament about claims from both sides and not run the risk of being deprived of all genuine moral principles through the ambiguity into which it easily falls. (Kant, 1996a, p. 60 [4: 405])

The wise person therefore needs and wants what practical philosophy has to offer because philosophy has a type of systematicity - a thoroughly thought-through system of concepts or principles by means of which to distinguish and analyse parts of our realities and lives- that helps us think clearly about the complex and complicated situations we may find ourselves in. This, in turn, also makes it easier to persevere in doing what is right when we don't feel like it and so helps us become more careful as we think through how to do things better.

Doing practical philosophy — even at the highest, most advanced levels — is therefore insufficient for pursuing the highest good well or living wisely. As we noted in the introduction, on this account, the highest good is to strive to bring happiness and morality into as harmonious a union as possible (Kant, 1996a, p. 282 [8: 279], p. 229 [5: 110-111]). Hence, Kant views himself as disagreeing with both the Epicureans and the Stoics: 'The Epicurean said: to be conscious of one's maxim leading to happiness is virtue; the Stoic said: to be conscious of one's virtue is happiness. For the first, prudence was equivalent to morality; for the second, who chose a higher designation for virtue, morality alone was true wisdom' (Kant, 1996a, p. 229 [5: 111]). Kant argues instead that wisdom requires us to know both happiness and morality. Moreover, because what is prudent is conditional (maxims relative to the person and situation) while morality is unconditional (objective principles obliging all rational beings), our aim—what the wise person does-is to strive intentionally to deserve to be happy by pursuing happiness within the framework set by morality, or within a framework set by a genuine commitment to treating all persons as having dignity. Notice too, though, that Kant-interpretations, according to which the best version of the highest good is the life of the sage, incur another version of Arendt's objection to the Western philosophical tradition. After 
all, on these interpretations, we should strive always and only to do what is right because it is right, and insofar as we are successful at realising this ideal, we do so with joy, in which case the reflective life of the sage becomes better than the lives of those who also pursue a conception of the good that integrates an earthly (embodied, social) conception of happiness. These accounts therefore invoke a new type of hierarchy: the best life becomes the as-purely-rational-life as possible (the moral life of the sage), while the lesser lives become lives that are also earth-bound-and Arendt's objection reinstantiates. On these accounts, our animalistic, affectionately social being-what Arendt puts into 'labour' and what Kant, as we will see below, puts into 'animality'-becomes something without a distinctive, important value in a rich human life, and, so, giving it up is not seen as giving up something valuable; indeed, giving it up by living the non-earthly or (purely) moral life of the sage is viewed as the ideal. ${ }^{\text {vi }}$

Regardless of these disagreements over the sage, note that we are now not surprised by Kant's claim that we must make truthfulness our most basic duty, that truthfulness is the only 'sacred command of reason' (Kant, 1996a, p. 613 [8: 427]). Truthfulness is constitutive of knowing what we are doing (which maxims we are acting on) and daring to learn what makes us truly happy. Without truthfulness, happiness and morality are beyond reach, let alone the project of pursuing happiness within the framework of morality - which is what the person with character or integrity does. Kant therefore says that

the only proof within a human being's consciousness that he has character is that he has made truthfulness his supreme maxim, in the heart of his confessions to himself as well as in his behavior toward everyone else; and since to have this is the minimum that one can demand of a reasonable human being, but at the same time also the maximum of inner worth (of human dignity), then to be a man of principles (to have a determinate character) must be possible for the most common reason and yet, according to its dignity, be superior to the greatest talent (Kant, 2007, p. 393 [7: 295]).

Living life with character or integrity is, in other words, something everyone can do-indeed philosophers are not more likely to be able to do this than other people-but doing so is impossible without truthfulness. ${ }^{\mathrm{vii}}$ Moreover, although doing philosophy brilliantly can bring us much welldeserved fame and admiration, we admire it less morally than we admire a person with integrity. Kant's philosophical brilliance bows, in other words, to the moral integrity of Sojourner Truth.

The challenge of wisdom, then, comes with learning to be truthful—to describe correctly what you do, including what motivates you to do what you do. Hence Kant relatedly proposes that you have a moral duty to

'know (scrutinize, fathom) yourself',... in terms of your moral perfection in relation to your duty. That is, know your heart-whether it is good or evil, whether the source of your actions is pure or impure, and what can be imputed to you as belonging originally to the substance of a human being or as derived (acquired or developed) and belonging to your moral condition.

Moral cognition of oneself, which seeks to penetrate into the depths (the abyss) of one's heart which are quite difficult to fathom, is the beginning of all human wisdom. For in the case of a human being, the ultimate wisdom, which consists in the harmony of a being's will with its final end, requires them ${ }^{\text {viii }}$ to remove the obstacle within (an evil will actually present in [them]) and then to develop the original predisposition to a good will within [them], which can never be lost. (Only the descent into the hell of self-cognition can pave the way to godliness)... This moral cognition of oneself will, first, dispel fanatical contempt 
for oneself as a human being (for the whole human race), since this contradicts itself... But such cognition will also counteract that egoistical self-esteem which takes mere wishes... for proof of a good heart. (Kant, 1996a, pp. 562-3 [6: 441])

Learning to describe oneself truthfully is not, then, an exercise in having contempt for everything distinctly human rather than merely rational. Rather, it is to learn what we like to do, what kinds of patterns of motivation — good, bad, and neutral—we are liable to have, and it is to learn to trust that the predisposition to good (more on this below) really is good. If we engage in our lives in this way, we can realise happiness in union with morality - the basic ends we set will not be at war with morality - and we can do so in a way that we can morally own and that makes us happy. Of course, whether we end up being happy is beyond our control—-there are too many accidents, including others' behaviours and lives, affecting this. But striving to deserve to be happy is a project that makes fundamental sense to beings like us, and it is the only one for which we can assume moral responsibility. ${ }^{\text {ix }}$

Even if one agrees with everything above as a matter of Kant-interpretation and sets aside possible disagreement regarding the Kantian sage, other aspects of Kant's practical philosophy still call out for critical engagement, correction and development. In particular, Kant's answer (and typical Kantian answers) to the question of how to make his theories of freedom (of virtue and of right) applicable to human nature generally, as well as to particular historical lives and societies, require serious rethinking. After all, Kant's own way of doing this often merely reproduces his own prejudices, while thinkers in the Kantian tradition tend to follow suit or never get the historical problems we are inheriting properly into view. To make this argument below, I first develop the methodological approach started in previous work, ${ }^{x}$ namely that when we switch from ideal theory (identifying objective principles of freedom) to focusing on the human condition and/or historical lives and societies, we must increasingly switch to a bottom-up, rather than top-down, investigative approach that requires careful listening and attention to the human lives in question. As we do, we can, however, still hold onto Kant's basic philosophical distinctions as captured by his 'predisposition to the good' ('animality', 'humanity', 'personality'), his 'propensity to evil' ('frailty', 'impurity', 'depravity'), as well as his basic ideas regarding how we develop, integrate, and transform ourselves by means of associative, abstract conceptual, and aesthetic-teleological thought. His philosophical systematicity remains extremely useful-indeed better than Arendt's-but in order to end up with wiser, more complete philosophical theories than Kant himself did and Kantians often do, it is crucial to listen carefully to, and strive to understand, the human lives and historical societies we are trying to critique with our theories. Then we-personally, as students, as thinkers-can figure out how to let the objective principles of freedom (the principles of virtue and of right) set the framework within which we can reform our inherited, partly dysfunctional institutions and pursue happiness individually or as a society. Let me explain, starting with a very brief sketch of the predisposition to good and the propensity to evil. ${ }^{\text {xi }}$

\subsection{Kant's Predisposition to Good and Propensity to Evil in Human Nature}

Kant's writings on anthropology, history, education, and religion have received increased attention recently, and with it, his three-fold accounts of both our embodied, social, rational nature and our ineliminable tendency to do bad things. On the latter point, in the Religion, Kant proposes that the predisposition to good in human nature consists of our reflexive and reflective self-conscious strivings to 'animality,' 'humanity,' and 'personality,' and that the propensity to evil comes in three degrees, namely 'frailty,' 'impurity,' and 'depravity. ${ }^{\text {xii }}$ As the related secondary literature is growing, it is unsurprising that we find a re-instantiation of many classical interpretive and philosophical debates, such as how to understand Kant's philosophical position as one of 'transcendental idealism' 
(rather than, simply, a rationalistic or empirical account) —and, so, also with debates regarding how to understand our cognitive abilities in relation to our animality. xiii Here I do not engage these debates, but merely show why I believe that to take on Arendt's challenges to the philosophical tradition, to appreciate core challenges regarding wisdom, (philosophical) education and moral improvement, and to appreciate the systematic strength of Kant's position relative to that of Arendt, it is philosophically important to view our animality as irreducibly reflexively self-conscious in nature and as working together with our natural vital force. ${ }^{\text {xiv }}$ On this basis, we can then appreciate how living well requires us to develop, transform and integrate our animality with our humanity and personality and to do so by means of our associative, abstract conceptual, and teleological-aesthetic cognitive powers. Because I provide a fuller engagement with Kant's accounts of the predisposition to good and the propensity to evil elsewhere, ${ }^{\text {xv }}$ here I merely sketch a few, core features that are particularly important for our current purposes.

Kant thinks that we have a three-fold nature consisting of 'animality,' 'humanity,' and 'personality.' Our animality (or what makes us 'living beings') is constituted by three reflexively selfconscious drives - to preserve ourselves, to have sex, and to develop affectionate community - that are fundamentally grounded in our natural 'vital force' (our embodied forcefulness). Each predisposition, in turn, is enabled by a relational category of the understanding-namely substance (self-preservation), causality (sex drive), and community (affectionate community) - which must here be understood teleologically, namely as orienting a new-born's ability to act in accordance with pleasures and pains such that the baby becomes a good and harmonious forceful whole. In other words, new-born babies strive to stay alive by sucking until they are full, and they find it pleasant to be touched gently and held affectionately. Their natural vital force is strong and good when these activities are organised by their caregivers in a teleological whole; in these cases, the cyclical combination between eating, rest, and affection results in an overall harmonious baby. That this is a reflexively self-conscious striving is seen exactly by how it is present in new-born babies' behaviours: babies cannot yet reason - they cannot use abstract concepts-in a reflectively self-conscious way (as an "I"). In addition, we see that this account of our animality is plausible because it helps us explain other animals' behaviour, too_and, indeed, we develop our animality in part through associative thinking like they do. ${ }^{\text {xvi }}$

In contrast to all other animal new-borns, however, human beings scream when they are born. To explain this philosophically, Kant proposes that we need to attribute an additional capacity for representation to human babies, namely that they scream to express frustration at their inability to act (Kant, 2007, p. 369 [7: 268]). It is this capacity for freedom that in time becomes transformed into the actual ability to act, in the sense of setting ends of one's own. In addition, it doesn't take many weeks before human babies start to smile and cry in a way that reveals a nascent ability to relate to an image of themselves, as seen by others. It is pleasant to be seen by loving caregivers and it is pleasant to see them, just as not being seen by or not seeing them is, at first, experienced as unpleasant. These two kinds of representation — of freedom and of a social sense of self-constitute the second predisposition to good in human nature, to humanity (or what makes us 'rational' beings). Developing this predisposition is a slow process because of its cognitive and emotional complexity. In particular, developing our ability to set ends of our own (to act on maxims) and to learn to manage our social sense of self requires us to develop reflective self-consciousness (to become able to use the self-reflective (I') as well as our abstract conceptual, associative, and aesthetic-teleological powers. For example, we must learn to master bodily movement and different kinds of social presentation, to use abstract concepts - apple, milk, table — to describe objects in the world, to appreciate which objects can be made into larger, more complex objects, to appreciate what we like and do not like, to associate various objects with dangers, to play, to reason, to appreciate beauty, and so on. All of this takes years for us to develop, from initial reaching towards 
objects in the crib to being able to set and pursue ends of our own, ends we want to pursue, and to do so well.

Finally — and this brings us to the third predisposition, to personality (or what makes us morally 'responsible' beings)—we must learn to act as motivated by our practical reason. We must become able to do something just because it is the right thing to do and to abstain from doing something just because it is wrong-and we must become able to do this even though we would like to do otherwise. In technical Kantian terms, we must become able to abstain from action if the maxim we want to act on is not universalisable, meaning that the end we would like to pursue is incompatible with treating ourselves or others with respect (as having dignity), and we must strive to create a world in which we flourish and where we assist others in their efforts to do the same. Developing moral character (personality) is therefore only possible because of our capacities for practical reason. It is revealed in or accompanied by 'moral feeling,' in our capacity for feeling the moral 'ought' or feeling bound by moral duty. Correspondingly, our moral aim is to develop a strong ability to act in these ways, which is to develop a strong moral vital force. Hence, if we return to the highest good, we can say that our aim in life is to develop our natural and our moral vital forces into as harmonious a whole as possible and with our moral vital force being strongest. If we succeed, then our moral vital force is experienced as, or feels like a precondition for, acting in the pursuit of particular ends that make us happy (perfect duties) and, insofar as life allows, as making it necessary for us to work towards a better future for humankind by developing our own talents and capacities and by assisting others in their pursuit of happiness (imperfect duties). .vii $^{\text {xi }}$

Kant's theory of human nature also contains an account of our propensity to evil. ${ }^{\text {xviii }}$ In short, in my preferred interpretation, evil is something we bring upon ourselves through our capacity for choice (setting ends of our own) and it comes in three degrees: 'frailty,' 'impurity,' and 'depravity.' Moreover, what distinguishes the degrees tracks how we can lose our way in life in increasingly more complex ways. Hence, frailty refers to an instance of wrongdoing, impurity to an emotionally unstable pattern of motivations determining our actions, and depravity to a striving to weaken our subjective susceptivity to act morally. Hence, a depraved heart always involves adopting 'evil maxims' and 'reversing the ethical order as regards the incentives of a free power of choice' in a self-deceptive manner (since humans do not have a 'diabolical' will) (Kant, 1996b, p. 78 [6: 30 ]). A depraved heart, in other words, always involves acting on a non-moral motivation in a self-deceived manner or doing something bad in the name of doing something good. In contrast, frailty and impurity can be done either self-deceptively or non-deceptively, though if we do so self-deceptively, it is more difficult to improve our ways. So, for example, a male colleague in a philosophy

department may interrupt his woman colleague just that once because he was having a truly horrible time in life and, somehow, this incident is just an outlet for his current inability to manage-and he might do it self-deceptively (saying things like 'it's not my fault; life is too hard and she was really annoying') or not self-deceptively, but affectively (saying things afterwards like 'I can't believe that I just did that! What a terrible thing I just did!'). This is frailty. Or how he treats his woman colleague always depends on how he's feeling that day: on good days, he doesn't interrupt, while on bad days, he does — and he might do it without self-deception (he acknowledges that he has a problem with interacting professionally with women) or with self-deception (he tells himself a story, according to which this (or these) colleague(s) deserve(s) to be treated in this way). This is impurity. Finally, he might never orientate himself around women respectfully, but to what extent he behaves professionally depends on what makes him feel better about himself in the moment. In situations where he wants to put a woman 'in her place,' he does that; in situations where he wants to show how committed he is to diversity to impress others, he acts accordingly. Generally, however, any actions of women that appear to affirm themselves as this male colleague's equal (rather than 
someone who fundamentally adores him as a subordinate, an unequal) will, potentially, incur his wrath: how dare she?! This is depravity.

In Kant's practical philosophy, this account of human nature complements his accounts of moral freedom (of virtue and of right), of the highest good, and of wisdom. Before turning to the places where Kant fails at writing wisely, where he engages in dehumanisation by means of philosophy), notice that there are several advantages to his overall theory as compared to Arendt's. A full comparison and analysis is impossible within the context of this paper, but let me sketch some of these points to indicate why my overall suggestion throughout this paper is that combining and transforming their various proposals may be the most productive approach. To start, using Kant's 'animality' rather than Arendt's 'labour' to capture our animalistic (embodied, social) nature clearly seems philosophically advantageous. Kant's account is better in that his use of the natural vital force and the relational categories of the understanding together yield a useful set of principles through which we can explore these animalistic aspects of ourselves. Notice, too, that this account of human nature appears to fare better than Arendt's in that her account is much more conservative because it makes biological life a pillar for 'labour' (as contrasted with Kant's account of animality). ${ }^{\text {xix }}$ These advantages are consistent with holding onto Arendt's central insight that our animality has its own distinctive value, and to realise this value-being in tune with our animalistic being in self-reflexive ways - is constitutive of realising a harmonious self. If we lose this connection, then we risk becoming ungrounded (alienated) — too reflective_which puts us at a distance from happiness and wisdom.

Relatedly, notice how Kant's multifaceted account of evil captures how, insofar as we (as individuals or as societies) have lost our way very seriously, we are likely to set irrational ends in the name of setting rational ones. Consistent with Arendt's writings on totalitarianism, Kant combines his idea of a depraved heart with the vices that can be grafted onto the predisposition to humanity in order to identify 'diabolical vices,' vices that capture the worst we humans can do (Kant, 1996b, p. 75 [6: 27]). Kant describes such diabolical destructive violence as rooted in an 'anxious endeavor' to obtain a 'hateful superiority' over others (Kant, 1996b, p. 75 [6:27]), since they attach to the predisposition to humanity (end-setting and a social sense of self). Such wrongdoing is characterised by an 'extreme degree of malignancy [, namely] ... a maximum of evil that surpasses humanity... e.g. in envy, ingratitude, joy in others' misfortune, etc.' (Kant, 1996b, p. 75 [6: 27]). ${ }^{\mathrm{xx}}$ These evils 'surpass' humanity in that they are not fully comprehensible by, as Arendt also says, common sense, rational self-interest, or humanly comprehensible motives. It appears constitutive of the worst of human evil to make others suffer as such or to create conditions of what we may call 'living death' (Arendt, 1948/73, pp. vii-ix). ${ }^{\text {xi }}$ Depraved violence attacks all of our embodied, social, rational being and aims to reduce us to focus all our agency on acting as if we were non-agents, to take away all of our spontaneity and to make us suffer to such an extent that lethal danger or suicide can present themselves subjectively as ways out. In this way, Kant's account of the depraved heart is useful not only to capture totalitarianism but all profound political evil (what Kant calls 'barbarism'). Moreover, in my view, Kant provides a philosophical account that can explain, as Arendt claims but doesn't ultimately provide a theory of, why totalitarianism attacks truthful descriptions of reality itself (Arendt, 1948/73, p. 9): a depraved heart is necessarily self-deceived, which is why a depraved heart always seeks destruction under the guise of being construction. Notice too that this account is consistent with Arendt's philosophical claim that insofar as modernity is characterised by a devaluing of our animality, fascist and totalitarian movements are more likely because our modern ability to feel our vulnerable, earthly animalistic being as valuable and harmonious is deeply flawed. This is why destroying it all or leaving the planet — another kind of suicide_can emerge as felt ways out for us. 
In addition - and still in the mode of merely sketching the outlines of the fuller accountsince a Kantian account can draw on the distinct analyses in all three critiques together with his writings on human nature, it can avoid a single-lens analysis of various kinds of objects. Not only does this make it relatively easy to draw distinctions between objects of labour and objects of work, but the overall account gives us philosophical resources with which to capture a wide array of objects, such as metaphysical objects, scientific objects, biological objects, teleological objects (tools), aesthetic objects, and so on. Finally, notice that the combination of Kant's account of virtue and of right yields much more systematicity with which to capture some (but not other) aspects of action than does Arendt's account. That is to say, Arendt's account is particularly good at capturing how good politics is an activity that requires outstanding people who can motivate others, speak together respectfully as equals on difficult topics, and succeed in creating a viable community. Kant's writings are not distinctively good at capturing these political aspects of our public lives, but they are extremely good at capturing more formal aspects of public reasoning. For example, his writings capture really well how being a good public leader is not only about being a good politician in Arendt's sense, but must also be able to use public principles of reason-principles of freedomagainst a background of wisdom, both of which in turn benefit from learning practical philosophy. Kant's account can therefore agree with Arendt's that the legal-political sphere (and its public reasoning) is not the same as the private (ethical) one, but his offers both distinctive principles of freedom suitable for each sphere (of right and of virtue). Together with Arendt's strengths regarding politics in terms of action, we are in a position where we can develop a truly powerful analysis of the public legal-political sphere.

The relative strength of Arendt's regarding politics is also related to a more general point of comparison. Despite all his philosophical brilliance, Kant's writings are not as wise, brave and good as Arendt's on central aspects of human life. Hence, in my view, Kant's general proposal regarding exactly how to accommodate human nature ('moral anthropology' (Kant 1996a, p. 372 [6: 217]) within his ideal theory of right, and how to apply his ideal theory of right to historical societies by means of what he elsewhere calls 'the principle of politics' (Kant 1996a, p. 614 [8: 429]), have crucial lessons to learn from Arendt as well as from other thinkers who broke with the norms of academia and academic philosophical writings. At the same time, however, and contrary to many scholars today, these thinkers could also have learnt a lot from Kant's writings on freedom. That is to say, Arendt's writings contain particularly deep analyses of the human tendency to evil from her perspective of entering academia as a 'pariah' (outcast) and having experienced the anti-Semitism of pre-World War II Germany and some aspects of European colonialism. Arendt's texts are not wise, however, in relation to, for example, women, (Black) racism, ${ }^{\text {xxii }}$ or LGBTQIA issues ${ }^{\text {xiii }}$. Moreover, if we want to read wiser political writings in these regards, written closer to Kant's own time with a distinctive philosophical voice, we do much better by turning to Mary Wollstonecraft, Ottobah Cugoano, Sojourner Truth, Frederick Douglass, Anna J. Cooper, W.E.B. Du Bois, or Lydia Maria Child, to mention just a few. Then again, some of these texts have distinctly racist (Wollstonecraft), sexist (Du Bois), heterosexist (most of them), etc. elements of a similar kind to those we find in Arendt (rather than Kant). Below I suggest that we can see these troubles as revealing some of Kant's general insights regarding the challenges of seeking wisdom as well as the ways in which his failures at achieving wisdom instantiated some of these problems - why doing practical philosophy is insufficient for wisdom as well as why wise people need practical philosophy. We also see one reason why some applications of Kant's philosophy and much Kantian theory go seriously wrong either by engaging in active dehumanisation of historically vulnerable social groups by means of philosophy or by a morally disturbing silence around issues of oppression and violence.

\section{TOWARDS WISER PHILOSOPHICAL EDUCATION AND THEORIES?}


If we look back at the practice of Western philosophy at universities in relation to our shared, human project of pursuing the highest good, some facts are striking. First, Western philosophy has provided conditions under which some truly brilliant, revolutionising philosophical systems and theories have been developed-with Kant's accomplishments, including his ideal theory of freedom, among the highlights. Second, the writings of these philosophers, including Kant, on human phenomena such as race, sex, gender, religion and culture are typically distinctly bad and, by any stretch of the imagination, unwise. They fail, in other words, to realise the effects of the predisposition to evil operating in their arguments. Third, for millennia, like most institutions on the planet-legal-political, religious, cultural, educational — universities remained a space only for a few, relatively privileged men. Fourth, the truly courageous and wise persons who moved our societies forward towards a more humane, free and diverse world through initiating or leading political, literary, cultural, religious movements were typically not academically trained philosophers or their students. Fifth, philosophy is today among the slowest academic disciplines to diversify — and it still does so with enormous resistance from those in power. As hinted above, I believe that Kant's account of human wisdom paradoxically helps us capture why the philosophical practice we are inheriting is bad in complex ways and why moving forward requires us to proceed differently than Kant himself did and more like Arendt in relation to so-called 'applied' or 'non-ideal' philosophy. In other words, as we move from our objective (ideal) theories of freedom to the human condition and historical societies, we need to switch from a top-down to a bottom-up method: from top-down application of pure principles to a recognition that the complexity of human life should be a starting point for some parts of more complete practical philosophical theories. Doing philosophy only from the bottom-up, however, is typically also insufficient to arrive at wisdom. Let me try to briefly explain and illustrate this point.

Alongside the growth of modern Western philosophy in universities as a site for privileged white men, there were some extraordinary philosophical minds striving to change the world for the better through literature, political writings and activism, as well as through creating alternative venues for pursuing their philosophical interests. It is impossible to do justice to all of them here, so let me mention just a few extraordinary persons and institutions as this is sufficient for our purposes. Queen Christina of Sweden (herself, according to most accounts, a member of the LGBT+ community), abdicated to pursue her philosophical interests in Rome, where she founded The Arcadia Academy in 1690 and insofar as her powers permitted, generally protected and promoted art, literature, philosophy, and tolerance (including for Jewish people). The 1600s also saw women like Margaret Cavendish and Anne Conway, who used their considerable social power and connections to break the ranks and write straightforwardly philosophical works - a tradition that was taken up by, for example, Mary Wollstonecraft and Mary Shepherd in subsequent centuries. From the 1700 s onwards, women also started to organise salons-with three of the most philosophically famous ones hosted by Émilie du Châtelet, Sophie de Grouchy, and Rahel Varnhagen. These institutions also broke with existing social norms by creating intellectual spaces that were open, in varying degrees, to artists, writers, and intellectuals who were, for example, nonaristocrats, non-Christians, or members of the LGBT+ community. The 1700s also saw the powerful, distinctly philosophical writing of Ottobah Cugoano on the horrors of European colonialisation and the Transatlantic slave trade. And in these centuries, we find women like Mary Ann Evans, who wrote deeply philosophical novels such as Middlemarch.

In North America, we find that many of the philosophical minds who were denied access to universities - and, in some cases, any education at all-became deeply involved in political activism, typically combined with literary and political writings. For example, we find the profound philosophical thinking of, as mentioned above, Sojourner Truth, the Grimke sisters, Frederick Douglass, Anna J. Cooper, Elizabeth Cady Stanton, and Lydia Maria Child. Among the great 
resources these thinkers left for us are philosophical reflections contained in journalist political writings, political speeches, literary writings, and autobiographies. As the various political movements gained success, women, people of colour, Jewish people, non-Christians more generally, and openly LGBTQIA+ people gained access to universities, and it didn't take long before new kinds of works began to appear in philosophy together with very philosophical works written in other disciplines. For example, we began to see deep, systematic, and distinctly philosophical works on class relations (with Karl Marx and Friedrich Engels as the two pioneers), on the sub-conscious (pioneered by Sigmund Freud), on sexuality and gender (pioneered by Simone de Beauvoir), on totalitarianism and anti-Semitism (pioneered by Hannah Arendt), on intersectionality involving Black women (pioneered by Anna Julia Cooper), and on Black racism (pioneered by W.E.B. Du Bois).

When we contrast all these 'bottom-up' writings with the 'top-down' writings of Kant and (until very recently) Kantians on issues regarding sex, race and gender, one is struck by the extraordinary difference in terms of careful attention to, engagement with, and vulnerability and wisdom around human oppression and suffering. This is not to say that these earlier, bottom-up critiques do not have blind spots and reveal prejudices-as mentioned above, they all do-but these shortcomings are at a different level than Kant's. Kant characteristically lacks vulnerability and careful engagement with the social identities he writes about and judges; often he even develops theories (of race, of gender, of sex) to support his prejudices rather than first getting to know the lives or aspects of life his prejudices track. Indeed, it seems plausible that it was often his own fears that drove what he said when he applied his theories to any issue involving sexuality and gender; knowing his own heart in these regards appears to have been much too difficult emotionally for him. ${ }^{\text {xiv }}$

Most Kantians in the last few decades have abandoned Kant's views on women, on gay life, and on race. However, this abandonment has often been combined with not saying anything at all about these issues or about non-ideal theory generally-a practice that Charles Mills $(2012,2017)$ has so usefully called the 'whitewashing' of the philosophical tradition. Others have instead kept Kant's 'us-them' way of formulating questions and answers, such as 'what shall we (representing the normative standard-heterosexual) think of gay sex (them)?' Finally, until recently, most Kantians (like much ideal theory) have tended to portray the above philosophical thinkers as not being worth listening to, as not having something distinct and interesting to contribute to mainstream philosophy. Instead, the tradition of applying the objective principles of freedom from the philosopher's armchair is common and presented as something all Kantians can do quite easily. My suggestion, then, is that when trying to think about these questions-including critiques of human phenomena such as sexuality, economic relations, race, gender, religion, etc.- - we must stay truthful philosophically to the fact that these investigations are contingent and consequently must, in important ways, proceed from the bottom-up, including as we also seek abstract principles and ideas. ${ }^{\text {xxv }}$ If we don't, we will continue the practice of developing brilliant, but unwise philosophical theories. ${ }^{\text {xvi }}$

Historically, as mentioned above, after more social groups were admitted to universities, non-ideal theories became much more complex in terms of systematicity. At the same time, however, theorists often overreached what their theories can show. For example, it is implausible to use Marx to analyse all aspects of our lives, from sexual violence to gender identity to arrogance to education to awe to stunning aesthetic beauty, while our practical philosophies must indeed cover all these spheres. It is also impossible to use Marx to, say, give a legal argument regarding bodily integrity that explains the difference between degrees of heinousness in different kinds of sexual assaults, which our legal philosophies must strive to do. If we try to say something about where we should take it from here-as individuals, as cultures, as legal-political societies-Marx has very little to offer. The best philosophical theories, in other words, need both elements: ideal theory as well as 
non-ideal theory that captures both the human condition generally ('moral anthropology') as well as particular lives and historical circumstances (the 'principle of politics'). Which is not to say that we cannot do one part at a time, or that we cannot use elements of each to analyse a particular human phenomenon more thoroughly. ${ }^{\text {xxvii }}$ Rather, it is to say that doing a part well requires awareness that one is doing exactly that part and not the whole. Finally, human freedom is only possible if we let the principles of freedom set the framework within which we pursue happiness as individuals and as societies. After all, if moral theories of freedom-like the ones we find in Kant-hadn't already started to take a hold on public culture and been so good at identifying what counts as justifiable public, legal and political (i.e. reason-based) arguments, it is unlikely that radical movements outside of academia would have succeeded either. The push towards freedom needed to come from both sides - the objective and the contingent; top-down and bottom-up_-and moving forward, our aim should be to transform also our philosophical tradition so that it unifies both forces and becomes wiser.

\section{ACKNOWLEDGEMENT}

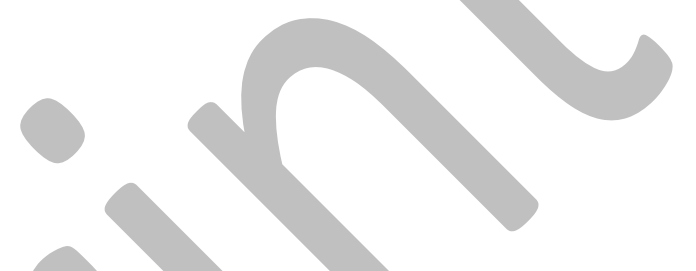

Thanks to David Bakhurst, Elvira Basevich, Mavis Biss, Lisa Chason, Sarah Clark Miller, Katerina Deligiorgi, Barbara Herman, Sarah Holtman, Huaping Lu-Adler, Jordan Pascoe, Susanne Sreedhar, Martin Sticker, Shelley Weinberg, Garrath Williams, Melissa Zinkin, Lorenzo Zucca, Rachel Zuckert and two anonymous reviewers for their generous engagement with this paper as it was developing.

\section{REFERENCE LIST}

Allais, L. \& Callanan J. (eds.) (2020) Kant and Animals (Oxford: Oxford University Press).

Arendt, H. (1973) The Origins of Totalitarianism (New York: Harcourt Brace Jovanovich). First published 1948.

Arendt, H. (1998) The Human Condition, $2^{\text {nd }}$ edition (Chicago: The University of Chicago Press). First published 1958.

Arendt, H. (2018) 'Remarks', in Thinking without a Banister: Essays in Understanding, New York: Schocken Books, pp. 476-484. First published 1973.

Aristotle (2000) Nicomachean Ethics. Edited and translated by R. Crisp (Cambridge: Cambridge University Press.

Belle, Kathryn Sophia (formerly Gines, Kathryn T.) (2014) Hannah Arendt and the Negro

Question (Bloomington: Indiana University Press).

Deligiorgi, K. (2020) 'Kant, Schiller, and the Idea of a Moral Self, Kant-Studien, 111.2, pp. 303-322. 
Kant, I. (2007) Anthropology, History, and Education. Edited by G. Zoller and R. B. Louden. Translated

by M. Gregor, P. Guyer, R. B. Louden, H. Wilson, A. W. Wood, G. Zoller and A. Zweig

(Cambridge: Cambridge University Press).

Kant, I. (1996a) Practical Philosophy. Edited and translated by M. J. Gregor (Cambridge: Cambridge University Press).

Kant, I. (1996b) Religion and Rational Theology. Edited and translated by A. W. Wood and G. di Giovanni (Cambridge: Cambridge University Press).

Mills, C. W. (2017) Black Rights/White Wrongs: The Critique of Racial Liberalism (Oxford: Oxford University Press).

Mills, C. W. (2012) 'Occupying Liberalism!', Radical Philosophy Review, 15.2, pp. 305-323.

Nagl-Docekal, H. (forthcoming) 'Feminist Perspectives on Kant's Conception of Autonomy: On the Need to Distinguish between Self-determination and Self-legislation', in S. Lettow and T.

Pulkkinen (eds), The Palgrave Handbook of German Idealism and Feminist Philosophy (London: Palgrave Macmillan).

O’Neill, Onora (1996). Towards Justice and Virtue: A Constructive Account of Practical Reasoning (Cambridge: Cambridge University Press).

Papish, Laura (2018) Kant on Evil, Self-Deception, and Reform (Oxford: Oxford University Press).

Varden, H. (forthcoming a) 'Response to Critics', SGIR Review.

Varden, H. (2021) 'Kant and Arendt on Barbaric and Totalitarian Evil', Proceedings of the Aristotelian Society, Vol. CXXI.2), pp. 221-248.

Varden, H. (2020a) Sex, Love, and Gender: A Kantian Theory (Oxford: Oxford University Press).

Varden, H. (2020b) 'Kantian Care', in A. L. Bhandary and A. Baehr (eds), Caring for Liberalism:

Dependency and Political Theory (Routledge), pp. 50-74.

Varden, H. (2020c) 'Kant and Moral Responsibility for Animals', in L. Allais and J. Callanan (eds), Kant and Animals (Oxford: Oxford University Press), pp. 157-175.

\footnotetext{
i See Varden, 2020 on why Kant's heterosexism is best viewed as a homophobia that is difficult to explain unless we attribute to him deep discomfort around his own sexuality.

ii My way is obviously not the only way to read these two thinkers, but it is one that takes seriously what they encourage us to do with their writings, namely to use them to think for ourselves. For example, see Arendt's related comments in 'Remarks' that 'each time you write something and you send it out to the world and it becomes public, obviously everybody is free to do with it what he pleases, and this is as it should be... You should not try to control whatever may happen to what you have been thinking for yourself. You should rather try to learn from what other people do with it'
} 
(p. 476), and Kant encouragement: 'Sapere aude! [Dare to be wise!] Have courage to use your own understanding ["Verstand"]" (WE 8: 35) in "An Answer to the Question: What is Enlightenment?', in Practical Philosophy. Moreover, this approach enables us to see ways in which the writings of Arendt and Kant can be combined to address topics that the philosophical resources of either one of them alone cannot do.

iii For a fuller discussion of each of labour, work, and action, see "Part III. Labor," "Part IV. Work," and "Part V.

Action" of (Arendt, 1958/98).

iv This is of course not to say that all sexual or erotic pleasure aims at orgasms. For more on these topics, see Varden (2020a).

v For another discussion of this difference, see Plato's on sexual pleasures in Gorgias.

vi Varden (2020a) presents another interpretation of the sage, namely as a moral ideal that we admire when we see it instantiated, such as in the Dalai Lama, but it would be a mistake to infer from this that the sage is the human ideal we should all strive to realise. For discussion on this point, see the interchange between Janelle DeWitt and myself in SGIR Review. [Provide a reference for this and add to the reference list.]

vii This is not to say that being truthful is sufficient for having moral integrity. Rather truthfulness, on this approach, is a precondition (necessary) for moral integrity.

viii Here I have rendered the text gender neutral to make it more consistent with the original, which uses the male noun (er) because the noun for human being (der Mensch) is a male noun in German.

ix See Katerina Deligiorgi (2020) for more on Kant's idea that striving to deserve to be happy makes rational sense even if we actually deserve to be morally happy but are not.

x See Varden, 2020a.

xi For Kant's account of the predisposition to good in human nature, see (Kant, 1996b, pp. 74-76 [6: 26-29]); for my interpretation and elaboration on these ideas, see Varden, 2020a, b.

xii 'Self-reflexive' consciousness means an awareness internal to any thought or action, whereas 'self-reflective' consciousness means a first-personal thinking about what one is thinking or doing and that one is the one doing it. Selfreflective consciousness is a second-order awareness of what I am already self-reflexively conscious of.

xiii See Callahan and Allais, 2020 for a recent collection of articles on Kant on animals.

xiv I believe Varden, 2020a is the first Kant interpretation that pays careful attention to this aspect of Kant's (and Kantian) practical theory.

xv For my basic take on these positions, as well as how they relate to debates in metaphysics and metaethics, see Varden, 2020a. For the contrast between Janelle DeWitt's more cognitive approach and my own, see our discussion regarding Sex, Love, and Gender forthcoming in SGIR Proceedings.

xvi For more on my take on Kant on animals, see Varden, 2020c.

xvii For more on my interpretation of Kant's on these points, including on his distinction between perfect and imperfect duties, see Varden (2020a).

xviii See Kant, 1996b (pp. 76-89) [6: 28-45)]) for his account of the propensity to evil in human nature, and Varden, 2020a for a fuller interpretation of his account. For an alternative approach, according to which self-deception is more pervasive in all evil, and an overview of much of the related, secondary literature, see Papish, 2018.

xix This, in my view, is central to why I could develop a Kantian account of sex, love, and gender that can overcome the mistakes and shortcomings of Kant's own position in Varden (2020a). It would be much more difficult to do the same within Arendt's philosophical framework.

xx Notice, though, that we are here talking about diabolical actions, not a diabolical will (which, we saw above, we don't have).

xxi For more on Arendt and Kant on political evil, see Varden (2021).

xxii For more on this, see Belle, 2014.

xxiii For one illustration of this, see the "Zur Person" interview here:

https://www.youtube.com/watch?v $=$ dsoImQfVsO4\&t=890s

xxiv For more on this, see Varden 2020a.

xxv This is one way in which I believe we can take on Onora O'Neill's important challenge that Kantians (and others) must strive to "abstract" and not "idealize" (understood as universalizing their own or other contingent ways of living life). See, for example, O’Neill (1996).

xxvi One unfortunate effect of this tends to be that Kantians and their critics do not engage with each other's works in productive, philosophically open-minded ways. For our purposes here, I set aside these controversies and instead focus on the Kant scholarship. For an overview over the entrance of women into Kant scholarship, see Varden, 2020a; for overviews over many of the historical, critical feminist engagements with Kantian thought and productive Kantian responses, see also Herta Nagl-Docekal, forthcoming.

xxvii I view Varden, 2020a to be doing the latter, to provide a more complete critique of sex, love, and gender. 